\title{
Gambaran Kasus Kematian pada Korban Terpapar Alkohol yang Diautopsi di Bagian Ilmu Kedokteran Forensik dan Medikolegal RSUP Prof. Dr. R. D. Kandou Periode 2014 - 2017
}

\author{
${ }^{1}$ Angela A. Pangemanan, ${ }^{2}$ James Siwu, ${ }^{2}$ Nola T. S. Mallo \\ ${ }^{1}$ Program Studi Pendidikan Dokter Fakultas Kedokteran Universitas Sam Ratulangi Manado \\ ${ }^{2}$ Bagian Ilmu Kedokteran Forensik dan Medikolegal Fakultas Kedokteran Universitas Sam \\ Ratulangi Manado \\ Email: angela.aprilia.pangemanan@gmail.com
}

\begin{abstract}
Alcohol is an addictive substance that could cause adverse effects to human body. Moreover, it is also related to a variety of criminal acts. North Celebes is one of the provinces with the highest alcohol consumption in Indonesia. This study was aimed to describe the death cases exposed to alcohol that were autopsied at Prof. Dr. R. D Kandou Hospital Manado during 2014-2017. This was a descriptive retrospective study using data of visum et repertum. The results showed that there were 17 death cases exposed to alcohol. The majority were in 2016 as many as 6 cases (35.3\%). The most common age group was 26-35 years as many as 7 cases $(41.2 \%)$. All cases were males (100\%). The most cause of death in these cases were due to violence using sharp objects as many as 15 cases (88.2\%). Conclusion: Most death cases exposed to alcohol were males aged 26-35 years, and the cause of death was violence using sharp object.
\end{abstract}

Keywords: alcohol, death cases

\begin{abstract}
Abstrak: Alkohol adalah zat adiktif yang dapat berdampak buruk bagi tubuh manusia serta terkait juga dengan berbagai tindakan kriminalitas. Sulawesi Utara merupakan salah satu provinsi dengan konsumen alkohol terbanyak di Indonesia. Penelitian ini bertujuan untuk mengetahui gambaran kasus kematian pada korban terpapar alkohol yang diautopsi di RSUP Prof. Dr. R. D Kandou periode 2014-2017. Jenis penelitian ialah deskriptif retrospektif menggunakan data hasil visum et repertum. Jenis penelitian ialah deskriptif retrospektif. Hasil penelitian mendapatkan 17 kasus kematian korban terpapar alkohol. Kasus terbanyak pada tahun 2016 yaitu 6 kasus (35,3\%). Kelompok usia terbanyak 26-35 tahun yaitu 7 kasus $(41,2 \%)$ dan jenis kelamin laki-laki (100\%). Penyebab kematian terpapar alkohol terbanyak karena kekerasan benda tajam yaitu 15 kasus $(88,2 \%)$. Simpulan: Sebagian besar kasus kematian akibat terpapar alkohol berada dalam kelompok usia 26-35 tahun, semua berjenis kelamin laki-laki, dengan jenis penyebab kematian akibat kekerasan benda tajam.
\end{abstract}

Kata kunci: alkohol, kasus kematian

Tindakan kejahatan dapat menimpa siapa saja baik laki-laki maupun perempuan tanpa melihat kalangan umur baik remaja, dewasa, atau lansia. Masalah minuman keras (miras) membawa dampak buruk kepada pengguna, kondisi pengguna, serta lingkungannya juga. Penyimpangan karena konsumsi alkohol menyebabkan kehilangan kesadaran yang beralih ke awal tindakan- tindakan melanggar hukum.

Konsumsi alkohol yang tidak bertanggung jawab merupakan salah satu penyebab terjadinya tindakan kriminal, kecelakaan, dan perilaku kekerasan., ${ }^{1,2}$ Survei World Health Organization (WHO) secara global mengenai alkohol dan kesehatan melaporkan sebanyak 320.000 orang berusia 15-29 tahun meninggal di seluruh 
dunia setiap tahun karena berbagai penyebab terkait dengan alkohol dan $5,1 \%$ kematian di dunia akibat penyakit berhubungan dengan konsumsi alkohol. ${ }^{1,3} \mathrm{Di}$ dunia, pada tahun 2000 diperkirakan 5 juta orang meninggal karena kecelakaan akibat alkohol dengan dominasi korban laki-laki. ${ }^{3}$

Sebanyak $70 \%$ narapidana menggunakan alkohol sebelum melakukan tindak kekerasan dan lebih dari $40 \%$ kekerasan dalam rumah tangga dipengaruhi oleh alkohol. Di Indonesia setiap tahunnya diperkirakan jumlah korban meninggal akibat miras mencapai 19.000 orang. ${ }^{4}$ Sulawesi Utara berada di peringkat ke dua di atas rata-rata konsumsi alkohol nasional dengan prevalensi $17,4 \%$. Sehubungan dengan hal ini maka Provinsi Sulawesi Utara membuat Peraturan Daerah (Perda) Nomor 4 Tahun 2014 tentang pengendalian dan pengawasan minuman beralkohol di Provinsi Sulawesi Utara. Meskipun telah dibuat peraturan daerah tersebut namun kenyataannya penjualan minuman beralkohol pada masyarakat semakin meningkat dan pengguna alkohol pada tahun 2015 semakin bertambah. ${ }^{5}$ Penelitian ini bertujuan untuk mengetahui gambaran kasus kematian pada korban terpapar alkohol yang diautopsi di RSUP Prof. Dr. R. D Kandou periode 2014-2017. Variabel penelitian ialah jumlah kasus kematian korban terpapar alkohol pertahun, usia, jenis kelamin, jenis penyebab kematian, dan tanda khas yang ditemukan pada jenazah.

\section{HASIL PENELITIAN}

Hasil pengumpulan data yang didapatkan berdasarkan hasil Visum et Repertum (VeR) pada kematian korban terpapar alkohol yang diautopsi di Bagian Ilmu Kedokteran Forensik dan Medikolegal RSUP Prof. Dr. R. D. Kandou selama periode 4 tahun yaitu pada tahun 20142017 mendapatkan sebanyak 17 kasus kematian. Tabel 1 memperlihatkan kematian korban terpapar alkohol paling banyak didapatkan pada tahun 2016 yaitu sebanyak 6 kasus dari total 183 kasus autopsi. Urutan kedua terbanyak dengan jumlah yang sama diduduki pada tahun 2014 dan 2017 sebanyak 4 kasus dari total 86 kasus kematian. Pada tahun 2015 terdapat 131 total kasus kematian, namun hanya didapatkan 3 kasus dengan terpapar alkohol. Hal ini menunjukkan bahwa tahun 2015 memiliki jumlah kasus kematian korban terpapar alkohol paling sedikit selama periode 2014-2017.

Tabel 1. Jumlah kasus kematian korban terpapar alkohol per tahun

\begin{tabular}{ccc}
\hline Tahun & Kasus & \% \\
\hline 2014 & 4 & 23,5 \\
2015 & 3 & 17,6 \\
2016 & 6 & 35,5 \\
2017 & 4 & 23,5 \\
Total & 17 & 100,0 \\
\hline
\end{tabular}

Tabel 2 menampilkan kematian korban terpapar alkohol menurut kelompok usia di Bagian Kedokteran Forensik dan Medikolegal RSUP Prof. Dr. R. D. Kandou Manado periode 2014-2017. Terbanyak didapatkan pada kelompok usia 26-35 tahun yaitu 7 kasus $(41,2 \%)$ dari 17 total kasus, diikuti oleh kelompok usia 17-25 tahun dan 36-45 tahun dengan jumlah kasus yang sama yaitu 4 kasus $(23,5 \%)$. Tidak didapatkan kasus kematian korban terpapar alkohol pada kelompok usia lansia.

Tabel 2. Distribusi kasus menurut usia

\begin{tabular}{ccc}
\hline $\begin{array}{c}\text { Kategori usia } \\
\text { (tahun) }\end{array}$ & Jumlah & \% \\
\hline $17-25$ & 4 & 23,5 \\
$26-35$ & 7 & 41,2 \\
$36-45$ & 4 & 23,5 \\
$46-55$ & 2 & 11,7 \\
$56-64$ & 0 & 0 \\
Total & 17 & 100 \\
\hline
\end{tabular}

Kematian korban terpapar alkohol yang diautopsi di Bagian Ilmu Kedokteran Forensik dan Medikolegal RSUP Prof. R.D. Kandou Manado periode 2014-2017 semua berjenis kelamin laki-laki dari total 17 kasus (100\%).

Jumlah kasus kematian korban 
terpapar alkohol yang masuk di Bagian Ilmu Kedokteran Forensik dan Medikolegal RSUP Prof. Dr. R. D. Kandou Manado selama periode tahun 2014-2017 dapat dilihat pada Gambar 1. Penyebab kematian terbanyak akibat kekerasan tajam yaitu 15 kasus $(88,2 \%)$. Penyebab kematian lainnya dalam tubuh ialah peradangan akut kelenjar ludah perut dan gagal jantung masing-masing 1 kasus $(11,7 \%)$. Tidak didapatkan jenis kematian akibat kecelakaan lalu lintas (KLL) dikarenakan semua kasus KLL tidak dilakukan pemeriksaan dalam dan jenis kematian akibat kekerasan seksual.

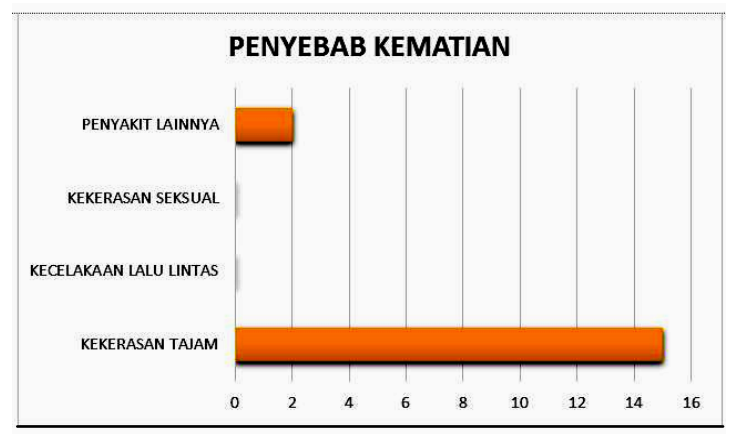

Gambar 1. Grafik jumlah kematian korban terpapar alkohol berdasarkan penyebab kematian

\section{BAHASAN}

Dari hasil penelitian dapat disimpulkan bahwa kematian korban terpapar alkohol di Bagian Kedokteran Forensik dan Medikolegal RSUP Prof. Dr. R. D. Kandou Manado selama periode 2014-2017 tidak cenderung meningkat ataupun menurun setiap tahunnya, melainkan bersifat fluktuatif atau tidak menentu. Penyebab hal ini diduga karena tidak semua korban terpapar alkohol dapat diidentifikasi dan sebagian tidak diizinkan untuk melakukan pemeriksaan dalam dari pihak keluarga. Terdapat juga kendala tergantung pada kondisi korban saat ditemukan. Pada kondisi jenazah yang sudah hancur seperti kasus KLL maka pemeriksaan dalam tidak dapat dilaksanakan akibat rusaknya organ, apalagi lambung karena dari kandungan lambung dapat diprediksi apakah sebelumnya korban mengonsumsi alkohol atau tidak.

Jika dilihat dari kelompok usia, kema- tian korban terpapar alkohol terbanyak dialami pada kelompok usia 26-35 tahun yaitu sebanyak 7 kasus $(41,2 \%)$. Hal ini sejalan dengan laporan nasional Riset Kesehatan Dasar 2007 yaitu prevalensi korban konsumen alkohol terbanyak pada jenjang usia 25-34 tahun berkisar 6,7\% dan $4,3 \%$, namun kemudian akan menurun dengan bertambahnya usia. ${ }^{5}$ Data penelitian ini menampilkan bahwa korban kematian akibat terpaparnya alkohol ialah 100\% berjenis kelamin laki-laki dengan jumlah 17 kasus di RSUP Prof. Dr. R. D. Kandou Manado. Hal ini sesuai dengan hasil riset Departemen Kesehatan RI 2008 yaitu di Indonesia menurut jenis kelamin lebih banyak dialami pada laki-laki. ${ }^{5}$ Penyebab terbanyak kematian akibat terpapar alkohol ialah kekerasan tajam yang memiliki persentase hampir $100 \%$ yakni $88,2 \%$, diikuti dengan penyebab kematian lainnya sebanyak 2 kasus saja $(11,7 \%)$, dan tidak didapatkan kasus kematian akibat KLL maupun kekerasan seksual. Hasil penelitian ini tidak selaras dengan RISKESDAS 2007 yang melaporkan bahwa di dunia pada tahun 2000 diperkirakan 5 juta orang meninggal karena kecelakaan akibat alkohol dengan dominasi korban laki-laki terlebih pada pengguna sepeda motor di Indonesia sebanyak 80,3\%, yang sudah mencakup kelalaian manusia termasuk mengonsumsi alkohol. ${ }^{3}$ Hasil yang berbeda ini mungkin disebabkan karena di RSUP Prof. Dr. R. D. Kandou, pada korban KLL tidak dapat dilakukan pemeriksaan dalam berhubung kondisi jenazah yang sudah cedera berat.

Data dari RSUP Prof. Dr. R. D. Kandou Manado periode 2014-2017 mengenai kasus kematian yang menunjukkan lambung berbau alkohol ini justru diduduki oleh penyebab kematian karena kekerasan tajam dengan ciri-ciri luka tusuk. Hal ini menunjukkan tanda kriminalitas terhadap mahluk hidup yang sesuai dengan pernyataan Atmasasmita ${ }^{6}$ seorang pakar hukum yaitu karena pengaruh minuman keras, seseorang dapat melakukan perbuatan kriminal seperti melakukan tindak kekerasan yang mengakibatkan terjadinya 
kerusakan baik fisik ataupun psikis. Penggunaan alkohol dalam jumlah cukup banyak akan mengakibatkan gangguan ketertiban dalam masyarakat. ${ }^{6}$ Hasil penelitian WHO tentang penyalahgunaan alkohol yang terjadi di Indonesia menurut WHO (WHO SEARO, 2002) dari tahun 1999-2000 memperlihatkan sebanyak 58\% angka kriminalitas terjadi di Asia Tenggara akibat pengaruh minuman keras. Terdapat dua penyebab yang jarang, diakibatkan oleh penyakit kronis. Hal ini sejalan juga dengan penelitian dari WHO, SEARO, 2002 bahwa di Indonesia tercatat lebih dari 350.000 orang meninggal karena penyakit kronis akibat konsumsi alkohol pada tahun $1998 .^{7}$ Tanda khas yang tersering ditemukan pada jenazah terpapar alkohol ialah lambung berbau alkohol pada perlakuan pemeriksaan dalam. Tanda-tanda lainnya termasuk pemeriksaan luar untuk mengetahui penyebab kematian saja, seperti yang sudah diklasifikasikan sebelumnya. ${ }^{8}$

Berdasarkan seluruh kematian yang masuk di Bagian Ilmu Kedokteran Forensik dan Medikolegal RSUP Prof. Dr. R. D. Kandou Manado periode 2014-2017, maka kasus kematian korban terpapar alkohol dikategorikan penyebab kematian yang fatal dan sangat penting untuk di waspadai. Sebagai mahluk sosial perlu dihimbau para pengguna untuk meminimalisir penggunaan alkohol yang akan mengarah ke tindakantindakan melanggar hukum beralih mengancam jiwa orang lain maupun diri sendiri.

\section{SIMPULAN}

Berdasarkan hasil penelitian dapat disimpulkan bahwa angka kejadian kema- tian korban terpapar alkohol tidak cenderung meningkat ataupun menurun tiap tahunnya, melainkan bersifat fluktuatif atau tidak menentu. Kematian akibat terpapar alkohol paling banyak terjadi pada kelompok usia 26-35 tahun, jenis kelamin laki-laki, lambung berbau alkohol sebagai tanda khas jenazah, dengan penyebab kematian akibat kekerasan benda tajam.

\section{DAFTAR PUSTAKA}

1. World Health Organization. The global status report on alcohol and health 2014. Geneva: WHO Press, 2014.

2. World Health Organization. The global status report on alcohol and health 2011. Geneva: WHO Press, 2011.

3. Suhardi. Preferensi peminum alkohol di Indonesia menurut Riskesdas 2007. Buletin Penelitian Kesehatan. 2011; 39(4):154-64.

4. Wiria MSS. Hipnotik-sedatif dan alkohol. In: Gunawan SG, Setiabudy R, Nafrialdi, Elysabeth, editors. Farmakologi dan Terapi. Jakarta: Balai Penerbit FKUI, 2009; p. 139-60.

5. Litbangkes RI. Laporan Nasional Riset Kesehatan Dasar 2007. Jakarta: Departemen Kesehatan RI, 2008.

6. Atmasasmita R. Teori dan Kapita Selekta Kriminologi. Bandung: PT Ersco, 1992.

7. Technical Expert Consultation. Development of Community Based Projects on the Prevention of Harm from Alcohol Abuse. Bali: WHO-SEARO, 2002.

8. Budiyanto A, Widiatmaka W, Sudiono $S$, Abdul Mun'im TW, Sidhi, Hertian S, et al. Ilmu Kedokteran Forensik. Jakarta: Bagian Kedokteran Forensik Fakultas Kedokteran Universitas Indonesia, 1997. 